\title{
Az alapjogok és a jogállamiság szerepének változása az európai integrációban ${ }^{1}$
}

\section{GÁT ÁKOS BENCE}

Az Európai Unió napjainkban fontos feladataként tekint a jogállamiság tagállamokban való érvényesitésére, amelyet alapitása óta létező, alapvető céljaként aposztrofál. Az alapjogokra és a jogállamiságra való hivatkozás azonban csak későn került be az európai alapszerzödésekbe. Az Unió és elödje, az Európai Közösségek jogfejlödését vizsgálva kiderül, hogy az elsö évtizedekben éppen a nemzeti hatóságok követeltek több alapjogi garanciát az európai intézményektöl. Az európai integráció intézményei elöbb fokozatosan próbáltak megfelelni ennek az elvárásnak. Az 1990-es évek végétöl következett csak be az a logikai változás, amelynek értelmében most már az uniós intézmények fogalmaznak meg egyre szigorúbb elvárásokat a tagállamokkal szemben.

Kulcsszavak: európai uniós alapjogvédelem, alapjogok és jogállamiság az európai alapszerződésekben, EUSZ. 7. cikk szerinti eljárás

\section{The change of the role of fundamental rights and Rule of Law in the European integration}

Nowadays, the European Union considers the protection of Rule of Law in the member states to be one of its most important duties from its very foundation. However, references to fundamental rights and Rule of Law have been relatively recently inserted in the Treaties. By examining the history of legal development of the EU and the preceding European Communities, it becomes clear that originally national authorities requested the European institutions to give more guarantees for the protection of fundamental rights. For a long time, the institutions of the European integration have tried to gradually meet these expectations. A change in this logic can be observed from the end of the 1990s, according to which EU institutions formulate more and more serious requirements against the member states.

Keywords: protection of fundamental rights in the European Union, fundamental rights and Rule of Law in the European Treaties, procedure of article 7 of the TEU

1 A tanulmány a szerző Küzdelem az európai szintéren - a Magyarországgal szembeni „jogállamiság”-kritika feltáratlan összefüggései címủ könyve alapján készült. GÁT 2019, 264. 


\section{Bevezetés}

Napjainkban gyakran hivatkoznak arra, hogy az európai értékek és a jogállamiság védelme jelentik az Európai Unió (a továbbiakban: Unió) „történelmi alappillérét”. Ez az érv különösen népszerű azok körében, akik szeretnék, hogy az Európai Unió olyan eszközökkel rendelkezzen, amelyeken keresztül ellenőrizheti a jogállamiság érvényesülését az egyes tagállamokban. ${ }^{2}$ Emiatt találkozhatunk olyan megállapításokkal, amelyek szerint a jogállamiság védelme mindig is az európai integráció fő célja és egyben alapvető feltétele volt, amely nélkül az egész európai jog értelmét veszítené. ${ }^{3}$ Az Európai Unió jogfejlődését alaposabban megvizsgálva azonban sokkal árnyaltabb képet kaphatunk. Egy ilyen vizsgálódásból kiderül, hogy - bár az európai államok demokratikus hagyományai kétségkívül fontosak - az Unió elődjét alkotó Európai Közösségek elsősorban nem értékalapú, hanem gazdasági együttműködést testesítettek meg. ${ }^{4}$ A következő oldalakon bemutatom, hogy az alapjogok és a jogállamiság védelmét csak viszonylag későn emelték be az alapítószerződésekbe. Ráadásul az európai alapjogvédelem kérdésköre eleinte más megközelítésben jelent meg, mint napjainkban. Az állampolgárok alapjogait legelőször nem a tagállamoktól, hanem az európai intézményektől féltették. Bár a jogállamiság eszméjét már-már bálványszerűen kezelő ${ }^{5}$ aktuális európai politika tükrében furcsának tűnhet, de eredetileg éppen a nemzeti hatóságok követeltek több alapjogi garanciát az állampolgárok számára az európai intézmények potenciális túlkapásaival szemben, és nem fordítva. A gondolat, hogy az állampolgárokat a tagállamok esetleges visszaéléseitől kell megvédeni, időben csak sokkal később nyert teret.

\section{Az alapjogok eredeti szerepe: garancia az európai intézményekkel szemben}

Egyes szerzők az 1953-as Európai Politikai Közösségről szóló szerződéstervezetre ${ }^{6}$ hivatkozva próbálják bizonyítani, hogy a tagállamok feletti jogállamisági ellenőrzés gondolata már a legelső pillanattól kezdve jelen volt az európai integrációban. A szerződéstervezet lehetővé tette volna, hogy a közösség felléphessen abban az esetben, ha egy tagállam területén „az alkotmányos rend és a demokratikus intézmények” ve-

2 Lásd: www.elysee.fr/declarations/article/initiative-pour-l-europe-discours-d-emmanuel-macronpour-une-europe-souveraine-unie-democratique/ (2017. 09. 29.)

3 Lásd például az Európai Bizottság 2014-ben kiadott közleményét. COM/2014/0158 final.

4 TÉGLÁSI 2014, 154.

5 Lásd: Varga Zs. András okfejtését a jogállamiság-fogalom önkényes, bálványszerű értelmezésének tendenciájáról. VARGA Zs. 2015.

6 Az Európai Politikai Közösséget létrehozó szerződés tervezetét az 1952 szeptemberében létrehozott - Paul-Henri Spaak volt belga miniszterelnök és külügyminiszter által irányított - ad hoc bizottság dolgozta ki és terjesztette az Európai Szén- és Acélközösség Parlamenti Közgyűlésének elnöke elé. A Közösség legfontosabb célkitűzései közé tartozott a tagállamok biztonságának a garantálása az agresszióval szemben, a tagállamok külpolitikájának összehangolása, a közös piac fokozatos kiépítése, valamint az emberi jogok és alapvető szabadságjogok védelme. https://europa. eu/european-union/about-eu/history/1946-1959/1953_hu (2019.01. 03.) 
szélybe kerülnek. ${ }^{7}$ Az említett szerződéstervezet azonban sohasem lépett hatályba, így legfeljebb történelmi kuriózumként tekinthetünk rá. A jogtörténeti tények ezzel szemben éppen arra világítanak rá, hogy az alapjogvédelem viszonylag új keletű téma az Európai Unióban.

Az Európai Közösségek első három évtizedében az alapító szerződések nem tettek említést az alapjogokról, csak néhány speciális jog védelméhez létezett jogalap. Ilyen jogok voltak például az állampolgárságon alapuló hátrányos megkülönböztetés tilalma, a munkaerő-áramlás szabadsága, a szolgáltatásnyújtás szabadsága, a munkavállalók munka- és életkörülményeinek a javítása, valamint a férfiak és nők közötti jövedelemegyenlőség. ${ }^{8}$ Ezek a kivételek azonban csak erősítik azt a megállapítást, hogy az Unió eredetileg meghatározóan gazdasági jellegü9 együttmüködés volt, hiszen a felsorolt jogok egytől-egyig gazdasági vonzatúak.

$\mathrm{Az}$ alapjogok szerződéses védelmének hiányát egy idő után az Európai Unió Bírósága (korábbi nevén Európai Közösségek Bírósága, a továbbiakban: Bíróság) igyekezett kompenzálni. ${ }^{10}$ A Bíróság a német Alkotmánybíróság híressé vált, 1974. május 29-i, úgynevezett „Solange” ítéletére reagálva szélesítette ki az alapjogvédelmi garanciákat. A karlsruhei bíróság említett ítéletében ugyanis leszögezte, mindaddig nem fogadja el a közösségi (uniós) jog nemzeti joggal szembeni elsőbbségét, amíg az Európai Közösségekben nem ugyanolyan mértékben biztosított az alapjogok védelme, mint Németországban. ${ }^{11}$

Az Európai Unió Bírósága első lépésként a tagállamok alkotmányos hagyományaira támaszkodva megállapította, hogy az alapjogok védelme része a közösségi jog általános elveinek. Ezzel biztosítani tudta például olyan jogok védelmét, mint az emberi méltóság, a személyi sérthetetlenség, a szólásszabadság, a törvény előtti egyenlőség, a kontradiktórius közigazgatási eljárás elvei, vagy a gondos ügyintézés elve. ${ }^{12}$ A Bíróság ezután új eszközöket talált ki, hogy kiszélesítse az alapvető jogok érvényesítését szolgáló jogalapot; így például a nemzetközi egyezmények - többek között az Emberi Jogok Európai Egyezménye - további inspirációs forrássá váltak számára.

A német Alkotmánybíróság 1986. október 22-i ítéletében, azaz majdnem 30 évvel az európai integrációt megalapító Római szerződés után kezdte csak megnyugtatónak találni az európai alapjogvédelmet. Ekkor puhított korábbi joggyakorlatán azzal, hogy megdönthető vélelmet állított fel, amely szerint az Európai Bíróság által biztosított védelem egyenértékünek tekinthető a német alkotmányos védelemmel.

Az Európai Közösségek hosszú ideig a fent bemutatott bírósági joggyakorlatfejlődés ellenére sem rendelkeztek saját alapjogvédő dokumentummal. A Parlament, a Tanács és a Bizottság 1977-ben elfogadott egy nagyon rövid, mindössze két

7 PeCH-KOCHENOV 2015.

8 Ferraro-Carmona 2015, 3.

9 VAUCHEZ 2014, 37.

10 TÉGLÁSI 2010, 23-24.

11 Ferraro-Carmona 2015, 4.

12 Ferraro-Carmona 2015, 6. 
bekezdésből álló nyilatkozatot, amelyben aláhúzták, hogy „rendkivül fontosnak tartják azoknak az alapjogoknak a tiszteletben tartását, amelyek a tagállami alkotmányokból és az emberi jogok és alapvetö szabadságok európai egyezményéből következnek". ${ }^{13}$ A nyilatkozat azonban csak szimbolikus deklarációként értékelhető. Egy alapjogokat tartalmazó dokumentum megalkotására tett első kísérlettel csak jóval később, a Maastrichti szerződés 1989-es előkészítésekor találkozhatunk. Az Európai Parlament (a továbbiakban: Parlament) ekkor megszavazott egy alapjogokat rögzítő határozatot, amelyet azonban a tagállamok az új szerződéssel kapcsolatos tárgyalások során nem fogadtak el. Ezt követően éveket kellett várni arra, hogy a kérdés újra az európai politika napirendjére kerüljön. Az Amszterdami szerződést előkészítő 1997-es tárgyalások alatt a Parlament ismét megpróbálta elérni, hogy az Unió saját alapjogi chartával rendelkezzen, ${ }^{14}$ de a javaslatot ezúttal sem építették be a szerződésbe. A Tanács akkori német elnöksége azonban segített napirenden tartani a kérdést, így végül az 1999-es kölni Európai Tanács következtetéseinek megfelelően 2000. december 7-én, a Nizzai Szerződéssel egy időben kihirdették az úgynevezett Alapjogi Chartát (a továbbiakban: Charta). Ugyanakkor a Chartát akkor még olyan intézményközi megállapodás formájában fogadták el, amelyet nem lehetett a szerződésekkel egyenértékűnek tekinteni. A szerződéseknek megfelelő jogi kötőerővel csak később, az Európai Alkotmány létrehozásáról szóló szerződés („alkotmányszerződés”) tervezetében ruházták volna fel. Mivel azonban a szerződéstervezet több tagállami népszavazáson elbukott, a Charta továbbra is megmaradt egyszerű intézményközti megállapodásnak.

Az Alapjogi Chartát végül csak alig több mint tíz évvel ezelőtt, a Lisszaboni Szerződés 2009-es hatályba lépésekor emelték a szerződések szintjére. A Charta csak az európai intézményekre alkalmazható, a tagállami intézkedések közül kizárólag azokra terjed ki, amelyek az európai jogot hajtják végre. Még ha az „európai jog végrehajtása" kitételt a Bíróság kiterjesztően is értelmezi, világos, hogy a Charta nem a tagállami kormányzatokkal, hanem az európai intézményekkel szemben hivatott védelmezni az alapjogokat.

Az Európai Unión belüli alapjogvédelem kérdése az Alapjogi Charta elfogadásával sem jutott nyugvópontra. Jelenleg is vita tárgyát képezi, hogy az Európai Unió csatlakozzon-e az Emberi Jogok Európai Egyezményéhez és ezzel - a tagállamaihoz hasonlóan - magára nézve kötelezőnek ismerje-e el az Emberi Jogok Európai Bírósága joghatóságát. Bár a Lisszaboni szerződés előirányozta, hogy az Európai Uniónak csatlakoznia kell az egyezményhez, a csatlakozásra a mai napig nem került sor, mivel az Európai Bíróság 2014. december 18-án, 2/13-as állásfoglalásában ${ }^{15}$ a csatlakozás ellen foglalt állást. Ez a mindmáig nyitott kérdés is azt mutatja, hogy az alapvető jogok és az Európai Unió kapcsolata korántsem olyan vitán felül álló, történelmi tény-

13 http://eur-lex.europa.eu/legal-content/FR/TXT/PDF/?uri=CELEX:31977Y0427(01)\&from=FR (2017. 10. 10.)

14 Ferraro-Carmona 2015, 8.

15 Lásd a Bíróság állásfoglalásáról készült elemzést. Popov 2015. 
kérdés, mint azt a tagállamokkal szembeni uniós jogállamiság-politika szorgalmazói feltüntetik.

\section{Az alapjogok megváltoztatott szerepe: korlát a nemzetállami politikával szemben}

Mint láttuk, az európai intézményekkel szembeni alapjogvédelem csak viszonylag későn jelent meg az európai integráció történetében. A tagállamokkal szembeni uniós alapjogvédelem még ennél is új keletűbb kérdés. Bár a két jelenség témáját tekintve hasonló - hiszen mindkét esetben az alapjogok védelméről beszélhetünk -, a mögöttük álló megfontolások homlokegyenest ellentétes logikát tükröznek.

Az első esetben ugyanis a tagállami hatóságok - például a német alkotmánybíróság - fogalmazták meg abbéli aggodalmukat, hogy az európai intézmények nem tartják kellőképpen tiszteletben az alapjogokat. A második esetben pedig már az európai intézmények fejezik ki azzal kapcsolatos aggályaikat, hogy a tagállamok nem óvják kellöképpen az alapjogokat és a jogállamiságot is magukban foglaló „európai értékeket”.

Ez egy bravúros, 180 fokos fordulatot jelent: míg korábban a nemzeti hatóságok jelentették a garanciát a hiányzó európai alapjogvédelemmel szemben, napjainkban az európai intézmények éppen ezeket a nemzeti hatóságokat jelölik meg az alapjogokra leselkedő fő veszélyforrásként. A tagállamok szemszögéből ezért joggal tűnhet úgy, hogy az európai intézmények nemcsak hogy elhárították a velük szemben kezdetekben megfogalmazott alapjogi kritikákat - például az Alapjogi Charta elfogadásával -, hanem a megközelítést ügyesen megfordítva, a figyelmet még át is terelték a tagállamokra. A jogtörténet segítségével az alábbiakban erről a folyamatról is pontosabb képet kaphatunk.

A jogállamiságra tett első európai közösségi (uniós) utalást egy politikai deklaráció tartalmazta. Az 1973-as koppenhágai európai csúcstalálkozó után az Európai Közösségek kilenc tagállama elfogadta a Nyilatkozatot az európai identitásról. A dokumentum megállapítja, hogy a tagországok „egy olyan közös életfelfogás bizonyosságában, amely az embereket szolgáló társadalmi rend megteremtésére törekszik, akarják a gazdasági haladás célját képező képviseleti demokrácia, a joguralom és a szociális igazságosság, valamint az emberi jogok betartását, mint az európai identitás alapelemeinek a védelmét". ${ }^{16}$

Ami az uniós alapszerződéseket illeti, a jogállamiságra történő első szó szerinti utalások csak 35 évvel az Európai Közösségek megalapítása után, az 1992-es Maastrichti szerződésben jelentek meg. A Maastrichti szerződés három alkalommal tesz említést a jogállamiságról. Először a Preambulumban rögzíti, hogy a Magas Szerződő Felek megerősítik „elkötelezettségüket a szabadság, a demokrácia, az emberi jogok

16 www.cvce.eu/obj/declaration_sur_l_identite_europeenne_copenhague_14_decembre_1973-fr02798dc9-9c69-4b7d-b2c9-f03a8db7da32.html (2017. 10. 10.) Magyar fordításhoz lásd: J. NAGY 2005. 
és alapvető szabadságok tiszteletben tartása és a jogállamiság elvei mellett”."17 Ezt követően, már a szerződés normatív részében, az unión kívüli harmadik országok vonatkozásában jelenik meg utalás a jogállamiságra. A harmadik országoknak biztosított fejlesztési együttműködéssel összefüggésben a szerződés kimondja, hogy „a Közösség ezen a területen folytatott politikája hozzájárul a demokrácia és jogállamiság fejlődésének és megszilárdításának általános céljához, valamint az emberi jogok és alapvető szabadságok tiszteletben tartásának célkitüzéséhez". ${ }^{18}$ Végül, a jogállamiság elvére való hivatkozás a szerződés közös kül- és biztonságpolitikára vonatkozó cikkében is megjelenik, amely rögzíti, hogy a kül- és biztonságpolitika egyik célja „a demokrácia és a jogállamiság fejlesztése és megerősítése, valamint az emberi jogok és alapvető szabadságok tiszteletben tartása".19 Mindez jól mutatja, hogy az 1990-es évek elején, a Maastrichti szerződés megalkotásakor a jogállamiság-védelem kérdése még nem az uniós tagállamok, hanem a harmadik országok vonatkozásában merült fel.

Bár a Maastrichti szerződés F. cikke nem említi kifejezetten a jogállamiságot, a további elemzésre való tekintettel mégis érdemes azt is felidéznünk itt:

„1) Az Unió tiszteletben tartja tagállamainak nemzeti identitását, amelyek kormányzati rendszerei demokratikus elveken alapulnak.

2) Az Unió a közösségi jog általános elveiként tartja tiszteletben az alapvető jogokat, ahogyan azokat az emberi jogok és alapvető szabadságok védelméről szóló, 1950. november 4-én Rómában aláírt európai egyezmény biztosítja, továbbá ahogyan azok a tagállamok közös alkotmányos hagyományaiból erednek."20

Ez a cikk elsősorban a tagállamok nemzeti identitásának tiszteletben tartására helyezi a hangsúlyt, majd tényként állapítja meg, hogy a tagállamok kormányzati rendszerei demokratikus elveken alapszanak. A (2) bekezdés jogszabályszövege értelmében az Európai Uniónak - és nem a tagállamoknak - kell tiszteletben tartania a tagállamok alkotmányos hagyományaiból és az emberi jogi egyezményből fakadó alapvető jogokat. Tehát az alapvető jogokkal kapcsolatban a Maastrichti Szerződés F. cikke nem a tagállamok, hanem az Európai Unió számára ír elő kötelezettségeket.

Az 1997-es Amszterdami szerződés ehhez képest jelentős megközelítésbeli változást hozott. Az új szerződéssel a Maastrichti Szerződés F. cikk (1) bekezdése helyébe a következő szöveg lépett:

„Az Unió a szabadság, a demokrácia, az emberi jogok és az alapvető szabadságok tiszteletben tartása és a jogállamiság elvein alapul, amely alapelvek közösek a tagállamokban."21

Az Amszterdami szerződés következtében az alapszerződés szövege a fő hangsúlyt már nem a tagállamok nemzeti identitásának tiszteletben tartására helyezi. A nemzeti identitásra vonatkozó rendelkezést az új szöveg is átveszi, de az előző szö-

17 Maastrichti szerződés, Preambulum.

18 Maastrichti szerződés, 130 U. cikk, 2. bek.

19 Maastrichti szerződés, J.1. cikk.

20 Maastrichti szerződés, F. cikk.

21 Amszterdami szerződés, 1. cikk (8) bek. 
veghez képest hátrébb, a (3) bekezdésbe helyezi át. Továbbá a szöveg bár elismeri, hogy a szabadság, a demokrácia, az emberi jogok és az alapvető szabadságok tiszteletben tartása, valamint a jogállamiság minden tagállam számára közös alapelveket jelentenek, azokat már az Európai Unió saját alapelveiként kezeli. Jogilag ez annyit jelent, hogy az Európai Unió számára lehetővé vált, hogy a tagállamok alkotmányos hagyományaira való utalás nélkül, közvetlenül is hivatkozhasson demokratikus fundamentumára, és azt akár a tagállamokkal szemben is felhozhassa. Az idézett cikk másik jellegzetessége, hogy immár sokkal részletesebben sorolja fel a demokratikus alapelveket, amelyek között ráadásul az alapszerződések történetében először jelenik meg szó szerint a jogállamiság is.

Ezek a módosítások már önmagukban jelzik, hogy fontos logikai változáson ment keresztül az alapjogvédelemmel kapcsolatos európai megközelítés. Az Amszterdami szerződéssel bevezetett, alábbi F.1. cikk pedig teljesen egyértelművé teszi a változást, amelynek eredményeképpen a tagállamok az uniós alapjogvédelem célkeresztjébe kerültek:

„1. A tagállamok egyharmada vagy a Bizottság javaslata alapján és az Európai Parlament hozzájárulásának elnyerését követően az állam-, illetve kormányfői összetételben ülésező Tanács, miután a kérdéses tagállam kormányát felkérte észrevételei benyújtására, egyhangúlag megállapíthatja, hogy a tagállam súlyosan és tartósan megsérti az F. cikk (1) bekezdésében említett alapelveket.

2. A Tanács, amennyiben ilyen megállapítást tett, minősített többséggel úgy határozhat, hogy a kérdéses tagállamnak az e szerződés alkalmazásából származó egyes jogait felfüggeszti, beleértve az e tagállam kormányának képviselőjét a Tanácsban megillető szavazati jogokat. Ebben az esetben a Tanács figyelembe veszi az ilyen felfüggesztésnek a természetes és jogi személyek jogait és kötelezettségeit érintő lehetséges következményeit."

E passzus az Európai Unióról szóló szerződés jelenlegi 7. cikkének - azaz a napjainkban a jogállamisági vitákkal kapcsolatban híressé vált „hetedik cikknek” - az őse. Az idézett F.1. cikk 1997-ben, 40 évvel az Európai Közösségek megalapítása után vezetett be először - az alapjogokon és a jogállamiságon alapuló - uniós tagállamokkal szembeni szankciós eljárást. A tagállamok csak ettől a pillanattól kezdve jelennek meg az alapvető jogokra és a jogállamiságra leselkedő, potenciális veszélyforrásként.

A 2001-ben elfogadott Nizzai szerződés tovább folytatta az Amszterdami szerződés által elindított tendenciát. A további változást az jelentette, hogy az említett cikk egy olyan előrejelzési mechanizmussal egészült ki, amely lehetővé tette, hogy az Európai Unió nemcsak a súlyos jogsértés megállapítása esetén, hanem már az említett jogok megsértésének „egyértelmü veszélye” esetén is felléphessen egy tagállammal szemben egy egyszerűbb eljárás keretében. Ez az újabb, kiegészítő eljárás nem nyújt lehetőséget szankciókra, csak annyit tesz lehetővé, hogy a Tanács „ajánlásokat” fogadjon el annak érdekében, hogy a szóban forgó tagállam megszüntesse a jogállamiságot veszélyeztető helyzetet. Továbbá a Nizzai szerződés értelmében a Tanács arra is 
lehetőséget kapott, hogy „független személyeket kérjen fel, hogy azok észszerü időn belül a kérdéses tagállamban fennálló helyzetről jelentést készítsenek".22

Mivel a tagállamokat célzó jogállamisági ellenőrzési lehetőségek uniós alapszerződésbe illesztése kilép abból a logikából, amely az európai integráció első négy évtizedét jellemezte, érdemes röviden kitérni arra, hogy mi állhat a fordulat hátterében. A bemutatott változások az 1990-es évek végén és a 2000-es évek elején következtek be, amely időszakot döntően az Európai Unió keleti bővítéséről szóló viták határozták meg. Az akkori vélekedés szerint a kommunista diktatúra elnyomása alól nemrégiben felszabadult kelet-közép-európai országokban a demokratikus értékek és a jogállamiság nem rendelkeztek olyan szilárd alapokkal, mint Nyugat-Európában. Ezt a hozzáállást kiválóan szemlélteti az is, hogy a kelet-közép-európai államoknak speciális alapjogi és jogállamisági kritériumrendszernek, az úgynevezett koppenhágai kritériumoknak ${ }^{23}$ kellett megfelelniük ahhoz, hogy felvételt nyerhessenek az Európai Unióba. Bertrand Mathieu francia alkotmányjogász professzor $A$ jog a demokrácia ellen? címủ művében rámutat arra, hogy Nyugat-Európában ez a megközelítés még mindig érvényben van a kelet-közép-európai tagállamokkal szemben. Példaként hozza fel a mai napig müködő, 1990-ben létrehozott Velencei Bizottságot, amelynek fő küldetése, hogy támogassa „a közép- és kelet-európai országokat abban, hogy teljes jogú tagjai lehessenek a demokratikus nemzetek családjának". ${ }^{24}$ Hasonló megállapításra jut Trócsányi László alkotmányjogász professzor is, aki szerint a jogállamisággal kapcsolatos vizsgálatok tekintetében más bírálat alá esnek az Unió régi és újonnan csatlakozott tagállamai. ${ }^{25} \mathrm{~A}$ jelenleg kialakulóban lévő jogállamiság-politikát kritikus szemmel figyelők ezért sokszor panaszkodnak az Unión belüli egyfajta kettős mércére, amely szerint az Unióban a kelet-közép-európai államokat a demokráciát és a jogállamiságot illetően még mindig „,eredendően gyanúsabbnak” tartják, mint a „szilárd demokratikus hagyományokkal" rendelkező nyugat-európai tagállamokat.

A kelet-közép-európai tagállamokkal szembeni kettős mércét megcáfolandó, az Európai Unióban gyakran hoznak fel egy tévhiten alapuló érvelést. Sokan úgy gondolják, hogy a tagállamokkal szembeni, jelenlegi 7. cikk szerinti szankciós eljárás ősét az 1999-es, ausztriai politikai helyzet miatt vezették be az uniós szerződésekbe. Nyugat-Európában ugyanis nagy port kavart az az eset, amikor a szélsőjobboldalinak tartott Jörg Haider pártja (FPÖ) az 1999. októberi ausztriai parlamenti választásokat követően bejutott az osztrák kormánykoalícióba. Az európai uniós tagállamok ekkor

22 Nizzai Szerződés, 1. cikk.

23 Az Európai Unióba való felvételhez szükséges bizonyos kritériumok teljesítése, amelyeket az Európai Tanács 1993-as koppenhágai ülésén állapítottak meg, innen a „koppenhágai kritériumok" elnevezés. A kritériumok a következők: a demokrácia, a jogállam és az emberi jogok érvényesülését garantáló intézmények stabilitása, a kisebbségi jogok tiszteletben tartása és védelme; működő piacgazdaság; képesség az Unión belüli versenyviszonyokkal és piaci erőkkel való megbirkózásra; a tagsággal járó kötelezettségek teljesítésére való képesség, valamint a politikai, gazdasági és pénzügyi unió célkitűzéseinek vállalása. https:/eur-lex.europa.eu/summary/glossary/ accession_criteria_copenhague.html?locale=hu (2019.01.03.) 
uniós szintű eszközök helyett hagyományos, bilaterális diplomáciai úton nyilvánították ki nemtetszésüket és próbáltak nyomást gyakorolni Ausztriára. A téves feltételezés szerint az uniós tagállamok később ebből az esetből tanulva rögzítettek az alapszerződésekben egy eljárást, amelyen keresztül az Európai Unió fel tud lépni, ha egy tagállamban sérül a jogállamiság. A kronológiát figyelembe véve azonban ez az eset nem befolyásolhatta a 7. cikk elődjének számító jogállamisági eljárás bevezetését, hiszen azt az 1997. október 2-án - tehát két évvel a kérdéses osztrák választások és kormányalakítás előtt - aláírt Amszterdami szerződés vezette be.

Visszatérve a jogállamiság európai integrációban való térnyerésére, a jelenleg is hatályos európai alapszerződések legutóbbi jelentős módosítását megvalósító, 2007-ben aláírt Lisszaboni Szerződést alaposabban is meg kell vizsgálni. A Lisszaboni Szerződés által még nagyobb hangsúly került az alapvető jogok és a jogállamiság védelmére.

Egyrészt az Európai Unióról szóló szerződés (EUSZ) Preambulumába bekerült egy új, részletesebb bekezdés, amely rögzíti, hogy a szerződő felek az ösztönzést „Európa kulturális, vallási és humanista örökségéből [merítik], amelyből az ember sérthetetlen és elidegeníthetetlen jogai, a szabadság, a demokrácia, az egyenlőség, valamint a jogállamiság egyetemes értékei kibontakoztak". Másrészt az EUSZ normatív része az alapelvek még részletesebb felsorolásával egészült ki, amelyeket a szerződés immár európai „értékeknek” hív. A lisszaboni szerződésmódosítás után az Európai Unióról szóló szerződés (EUSZ) új, 2. cikke az alábbiakat tartalmazza:

„Az Unió az emberi méltóság tiszteletben tartása, a szabadság, a demokrácia, az egyenlőség, a jogállamiság, valamint az emberi jogok - ideértve a kisebbségekhez tartozó személyek jogait - tiszteletben tartásának értékein alapul. Ezek az értékek közösek a tagállamokban, a pluralizmus, a megkülönböztetés tilalma, a tolerancia, az igazságosság, a szolidaritás, valamint a nők és a férfiak közötti egyenlőség társadalmában."

Harmadrészt, a Lisszaboni szerződés az EUSZ 7. cikkének formájában megerősítette azokat a megoldásokat, amelyeket az Amszterdami és Nizzai szerződések vezettek be arra az esetre, ha a jogállamiság sérül egy tagállamban. Néhány technikai módosítás történt, a szerződés szövegéből például kivették azt a lehetőséget, hogy a Tanács jelentéskészítésre kérhet fel független személyeket arról, hogy milyen helyzetben van a jogállamiság egy adott tagállamban. A további elemzéseket megkönnyítendő, a jelenleg is hatályos 7. cikket érdemes teljes egészében idéznünk.

"(1) A Tanács, a tagállamok egyharmada, az Európai Parlament vagy az Európai Bizottság indokolással ellátott javaslata alapján, tagjainak négyötödös többségével és az Európai Parlament egyetértésének elnyerését követően megállapíthatja, hogy fennáll az egyértelmű veszélye annak, hogy egy tagállam súlyosan megsérti a 2. cikkben említett értékeket. Mielőtt ilyen megállapítást tenne, a Tanács meghallgatja a kérdéses tagállamot, és ugyanezen eljárásnak megfelelően ajánlásokat tehet neki.

A Tanács rendszeresen ellenőrzi, hogy azok az okok, amelyek alapján ilyen megállapítást tett, továbbra is fennállnak-e. 
(2) A tagállamok egyharmada vagy az Európai Bizottság javaslata alapján és az Európai Parlament egyetértésének elnyerését követően, az Európai Tanács, miután a kérdéses tagállamot felkérte észrevételei benyújtására, egyhangúlag megállapíthatja, hogy a tagállam súlyosan és tartósan megsérti a 2. cikkben említett értékeket.

(3) A Tanács, amennyiben a (2) bekezdés szerinti megállapításra jutott, minősített többséggel úgy határozhat, hogy a kérdéses tagállamnak a Szerződések alkalmazásából származó egyes jogait felfüggeszti, beleértve az e tagállam kormányának képviselojjét a Tanácsban megillető szavazati jogokat. Ebben az esetben a Tanács figyelembe veszi az ilyen felfüggesztésnek a természetes és jogi személyek jogait és kötelezettségeit érintő lehetséges következményeit.

A kérdéses tagállamnak a Szerződések szerinti kötelezettségei minden esetben továbbra is kötik ezt az államot.

(4) A Tanács a későbbiekben minősített többséggel úgy határozhat, hogy a (3) bekezdés alapján hozott intézkedéseket megváltoztatja vagy visszavonja, amennyiben az elrendelésükhöz vezető körülményekben változás következett be.

(5) Az e cikk tekintetében az Európai Parlamentre, az Európai Tanácsra és a Tanácsra alkalmazandó szavazási szabályokat az Európai Unió működéséről szóló szerződés 354. cikke állapítja meg."

Az EUSZ 7. cikke az Amszterdami és Nizzai Szerződések által rögzített megoldásokat megtartva két eljárástípust alakít ki. Az első típusú, a 7. cikk (1) bekezdése szerinti eljárás lehetővé teszi annak megállapítását, hogy, fennáll az EUSZ 2. cikkében felsorolt értékek súlyos sérelmének egyértelmű veszélye, valamint lehetőséget nyújt nem kötelező erejủ ajánlások megfogalmazására. Ez az eljárás indítható el könnyebben, az Európai Bizottság, az Európai Parlament vagy a tagállamok egyharmadának kezdeményezésére. Ezután a súlyos jogsértés egyértelmű veszélyének megállapításához a Tanács négyötödös többségére és az Európai Parlament egyetértésének elnyerésére van szükség. Ahhoz, hogy ezek a feltételek mind érvényesüljenek, komoly politikai manővereket kell végrehajtani diplomáciai szempontból rendkívül érzékeny területen, ahol az egyes európai országok egymást veszik górcső alá.

A második típusú, a 7. cikk (2) bekezdése szerinti eljárás alapján már az EUSZ 2. cikkében felsorolt értékek súlyos és tartósan fennálló sérelmét lehet megállapítani. Ezt az eljárást már csak a a tagállamok egyharmada vagy a Bizottság indíthatja el, a Parlament nem. A végleges határozat elfogadásához - amely már szankciókat is vonhat maga után az adott tagállammal szemben - a tagállamok állam-, illetve kormányfőinek egyhangú szavazatára (leszámítva az érintett tagállamot) és a Parlament egyetértésére van szükség. Az eljárás kudarcához tehát már az is elegendő, hogy egyetlen tagállam védelmébe vegye a vizsgálat alá vett országot, és megvétózza az ellene készülő határozatot az Európai Tanácsban. A szankciós döntéshez szükséges szavazási feltételeket különösen nehéz teljesíteni abban az esetben, amikor az Európai Unió nemcsak egy, hanem több tagállamot is bírál a jogállamiságra hivatkozva, hiszen a két tagállam nagy eséllyel szolidáris lesz egymással, és egyikük mindig megvétózza a másik ellen javasolt szankciókat. 
A fentiekre tekintettel a 7. cikk szerinti eljárásokat elindító politikai erőknek számolniuk kell azzal a politikai kockázattal, hogy az elindított eljárás eredménytelenül záródhat. A 7. cikket nem hiába szokták politikai „atomfegyverként” aposztrofálni. Egyrészt, egy tagállam szavazati jogának esetleges felfüggesztése példátlanul súlyos szankciót jelent az Unió jogrendszerében. Másrészt, a mechanizmus elindítása negatívan hathat vissza azokra is, akik elindították. Végül a 7. cikk szerinti eljárás alkalmazása az egész Európai Unió egységét megbonthatja azzal, hogy gyengíti a különböző európai országok közötti politikai bizalmat és kölcsönös jóhiszeműséget. Részben a 7. cikk ezen tulajdonságaival indokolható, hogy az elmúlt évtizedben az Európai Unió különböző intézményei nem a 7. cikk szerinti eljárások alkalmazására, hanem a megindítása előtti vizsgálati szakasz kialakítására helyezték a hangsúlyt, ezzel is növelve politikai mozgásterüket a tagállamokra vonatkoztatott jogállamiság- és alapjogvédelem terén. Az Unió által feltalált, illetve napjainkban előirányzott új jogállamisági mechanizmusok vizsgálata számos érdekes megállapítást tesz lehetővé, amelyekre külön cikkben szeretnék részletesebben kitérni.

\section{Zárszó}

A fentiekben annak bemutatására koncentráltam, hogy az uniós jogfejlődés tekintetében a jogállamiság nem tekinthető az európai integráció alappillérének. Eleinte éppen a tagállamok, illetve a tagállami hatóságok vetették vigyázó szemüket az európai integráció intézményeire, attól tartva, hogy utóbbiak működésük során nem biztosítják kellőképpen az alapjogvédelmet. Az európai intézmények több évtizedes fejlődés következtében vetkőzték csak le ezeket a kritikákat, miközben az 1990-es évek végétől fokozatosan teret nyert a tagállamok feletti európai alapjogi és jogállamiság-kontroll gondolata.

\section{Felhasznált irodalom}

Mathieu, Bertrand (2017): Le droit contre la démocratie? Issy-les-Moulineaux, LGDJ, collection Forum.

Ferraro, Francesca - Carmona, Jesús (2015): Les droits fondamentaux dans l'Union européenne. Le rôle de la Charte après le traité de Lisbonne. Brüsszel, Európai Parlament Kutatószolgálata. DOI: https://doi.org/10.2861/592904

GÁт Ákos Bence (2019): Küzdelem az európai színtéren - a Magyarországgal szembeni „jogállamiság”-kritika feltáratlan összefüggései. Budapest, Közép- és Kelet-európai történelem és társadalom kutatásért Közalapítvány.

J. NAGY László (2005): Az európai integráció politikai története. Szeged. Elérhető: http://publicatio. bibl.u-szeged.hu/3325/1/EUINTEGR.pdf (2018. 09. 23.)

PeCh, Laurent - Kochenov, Dimitry (2015): Renforcer le respect de l'État de droit dans l'UE: Regards critiques sur les nouveaux mécanismes proposés par la Commission et le Conseil. Elérhető: www.robert-schuman.eu/fr/questions-d-europe/0356-renforcer-le-respect-de-l-etat-dedroit-dans-l-ue-regards-critiques-sur-les-nouveaux (2017. 10. 10.) 
Popov, Athanase (2015): L'avis 2/13 de la CJUE complique l'adhésion de l'Union européenne à la CEDH. La Revue des Droits de l'Homme, 2015. február. DOI: https://doi.org/10.4000/revdh.1065

TÉGLÁsi András (2010): A tulajdonhoz való jog védelme Európában - az Európai Unió Bírósága, az Emberi Jogok Bírósága és a magyar Alkotmánybíróság gyakorlatának fényében. Kül-Világ, 7. évf. 4. sz. 22-47.

TÉGLÁSI András (2014): Az emberi jogok védelmének nemzetközi rendszere. In BENDE Zsófia HALÁsz Iván szerk.: Összehasonlitó alkotmányjog. Fejezetek az alkotmány, az állam, az államszervezet és az alapvető jogok témaköréből. Budapest, Nemzeti Közszolgálati Egyetem Közigazgatás-tudományi Kar.

TRÓCSÁNYI László (2014): Az alkotmányozás dilemmái. Alkotmányos identitás és európai integráció. Budapest, HVG-ORAC.

VArga Zs. András (2015): Eszményből bálvány? A joguralom dogmatikája. Budapest, Századvég Kiadó.

Vauchez, Antoine (2014): Démocratiser l'Europe. Párizs, Éditions du Seuil et La République des Idées.

\section{Jogforrások}

Amszterdami szerződés. Elérhető: www.parlament.hu/irom37/9171/alapszerzodes/xv_11997d-hu. pdf (2017. 10. 10.)

Egyesítési Szerződés

Egységes Európai Okmány. Elérhető: https://eur-lex.europa.eu/legal-content/HU/TXT/HTML/?uri=LEGISSUM:xy0027\&from=HU (2020. 04. 24.)

Európai Unióról szóló Szerződés. Európai Unió Működéséről szóló Szerződés. Elérhető: https:// eur-lex.europa.eu/legal-content/HU/TXT/HTML/?uri=CELEX:12012M/TXT\&from=HU (2020. 04. 24.)

Maastrichti szerződés. Elérhető: https://europa.eu/european-union/sites/europaeu/files/docs/ body/treaty_on_european_union_en.pdf (2017.10.10.)

Nizzai Szerződés. Elérhető: https://eur-lex.europa.eu/legal-content/EN/TXT/PDF/?uri=CELEX:12001C/TXT\&from=HU (2017. 10. 20.)

Római szerződés (EGK). Elérhető: https://eur-lex.europa.eu/legal-content/HU/TXT/HTML/?uri=LEGISSUM:xy0023\&from=HU (2020. 04. 24.)

\section{Internetes források}

COM/2014/0158 final. A Bizottság közleménye az Európai Parlamentnek és a Tanácsnak. A jogállamiság megerősitésére irányuló új uniós keret. Európai Bizottság, Strasbourg, 2014. március 11. Elérhető: https://eur-lex.europa.eu/legal-content/HU/TXT/HTML/?uri=CELEX:52014DC0158\&qid $=1592904002113 \&$ from $=\mathrm{EN}(2017.09 .29$.)

Emmanuel Macron beszéde 2017. szeptember 26-án egy szuverén, egységes és demokratikus Európáért. Elérhető: www.elysee.fr/declarations/article/initiative-pour-l-europe-discours-d-emmanuel-macron-pour-une-europe-souveraine-unie-democratique/ (2017. 09. 29.)

Az Európai Parlament, a Tanács és az Európai Bizottság közös nyilatkozata az alapvető jogokról, 1977. április 27. Elérhető: http://eur-lex.europa.eu/legal-content/FR/TXT/PDF/?uri=CELEX:31977Y0427(01)\&from=FR (2017. 10. 10.) 
Az alapjogok és a jogállamiság szerepének változása az európai integrációban

Az Európai Unió története - 1953. Elérhető: https://europa.eu/european-union/about-eu/history/1946-1959/1953_hu (2019.01.03.)

Nyilatkozat az európai identitásról, 1973. december 14., francia nyelvű változat. Elérhető: www.cvce. eu/obj/declaration_sur_l_identite_europeenne_copenhague_14_decembre_1973-fr-02798dc99c69-4b7d-b2c9-f03a8db7da32.html (2017. 10. 10.)

https://eur-lex.europa.eu/summary/glossary/accession_criteria_copenhague.html?locale=hu (2019. 01. 03.) 